\title{
Effect of Low- level laser therapy (LLLT) on Orthodontic Tooth Movement - Cellular Level
}

\author{
Sushma Dhiman* and Saba Khan \\ Orthodontics and Dentofacial Orthopedics, Aligarh Muslim University, India
}

Submission: February 04, 2017; Published: February 19, 2018

*Corresponding author: Sushma Dhiman, Orthodontics and Dentofacial Orthopedics, Aligarh Muslim University, India, Tel: 8527214151;

Email: sushmadhiman83@gmail.com

\begin{abstract}
Low-level laser therapy has been used to stimulate the orthodontic tooth movements (OTM). Low level laser therapy has biostimulatory effects. In the last decade, researchers have attempted to determine the affect of Low level laser therapy on the pathways and cells directly associated with orthodontic tooth movement. The results of studies on the rate of tooth movement are controversial. While the majority of published research outcomes indicate an increase in the rate of tooth movement after laser therapy compared to controls, but others reported no difference or even indicated the inhibitory effect of laser therapy on the rate of tooth movement. Most of the studies reported the effect of the LLLT on rate of orthodontic tooth movement but only few have dealt with the underlying mechanism of action of low- level laser therapy on cells involved in orthodontic tooth movement. The present paper discusses the effect of low level laser therapy on orthodontic tooth movement at cellular level.
\end{abstract}

\section{Introduction}

Orthodontic tooth movement occurs in the presence of a mechanical stimuli will cause changes in the microenvironment around the PDL due to alterations of blood flow, leading to the secretion of different inflammatory mediators such as cytokines, growth factors, neurotransmitters, colony-stimulating factors, and arachidonic acid metabolites. As a result of these secretions, remodeling of the bone occurs [1,2]. Bone remodeling involves resorption of bone on the pressure site and bone formation on the tension site [3]. Low level laser therapy has biostimulatory effects [4]. It stimulates the on-going biological process in tissue and has been found to be effective in modulating cell activity and production of endogenous molecules, which are also involved in orthodontic tooth movement [5-7].

In the last decade, researchers have attempted to determine the affect of LLLT on the pathways and cells directly associated with orthodontic tooth movement. The results of studies on the rate of tooth movement are controversial. While the majority of published research outcomes indicate an increase in the rate of tooth movement after laser therapy compared to controls [8-15], but others reported no difference [16-18] or even indicated the inhibitory effect of laser therapy on the rate of tooth movement [19]. Most of the studies reported the effect of the LLLT on rate of orthodontic tooth movement but only few have dealt with the underlying mechanism of action of LLLT on cells involved in orthodontic tooth movement.

\section{How does LLLT work?}

Effect of LLLT is photochemical not thermal. Response of a cell to LLLT occurs by absorption of light by photoacceptor molecule also termed as chromophores [20,21]. Cytochrome $\mathrm{C}$ oxidase is a key photoacceptor of light in the far-red to near-IR spectral range [22]. Cytochrome $\mathrm{C}$ oxidase is an integral membrane protein of mitochondria that contains four redox active metal centers. The Excitation of this molecule with light energy accelerates the rate of electron transfer [23] and in turn increases the capacity of mitochondria to generate ATP [20,24-26]. Increased ATP results in increased energy available for that cell's metabolic processes.

Low level laser therapy's effect on main cellular components involved in orthodontic tooth movement: In the last few decades, researchers have attempted to determine the affect of LLLT on the biological pathways involved in orthodontic tooth movement. Some authors believe that LLLT induces osteoblasts proliferation (in vivo studies, [27-28] and in vitro studies [2938]. Which is responsible for the accelerated tooth movement. However, according to other researchers, bone resorption is the rate-limiting step in tooth movement [36]. Therefore, any procedure which has the potential to increase osteoclastic activity may increase the rate of orthodontic tooth movement. Recent studies highlight enhanced osteoclastic activity after low level laser therapy in vivo [39-44] and in vitro [45]. 
Low level laser therapy's effect on osteoclast factors: The control mechanism of bone turnover is the OPG/RANKL/ RANK system which is also recognized as the final mediator of osteoclastogenesis [46,47]. Researchers have sought ways to determine which member(s) of the system is/are affected by LLLT.

\section{LLLT Effects On RANK and RANKL}

Activation and maintenance of osteoclastic activity is under control of binding of RANKL with RANK. When RANKL dock with RANK, preosteoclasts differentiate and become osteoclasts. Studies have observed greater number of RANK and RANKL positive cells in laser treated groups than in both the non-irradiated. $[8,40,45]$

\section{LLLT Effects on OPG}

Osteoprotregrin (OPG) competes with RANK for the binding of RANKL. OPG decreases the differentiation and activation of osteoclasts. Fujita et al. [8] found that the level of OPG expression between the laser and control group did not vary [8]. Kim's group reported a significant increase of the cytokine with LLLT application. But they also noted that magnitude of OPG upregulation was not as great as it was for RANK. Because the OPG to RANK ratio was skewed in favor of RANK, the team observed a net increase in osteoclastic differentiation and activation [40].

\section{LLLT Effects on other Osteoclast Factors}

Dozens of cytokines, hormones, and peptides have been proven to play a role in bone turnover. A review of the literature yields a number of reports indicating how some of the factors involved in osteoclast regulation may be affected by LLLT [45-61].

\section{LLLT and Transforming Growth Factor Beta 1}

Transforming Growth Factor Beta 1 (TGF- $\beta 1$ ) is integral in the differentiation and in maintaining the function of osteoclasts [68]. Research teams have discovered that sufficient expression of the polypeptide upregulates RANKL levels in the absence of osteoblasts, while excessive amounts of TGF- $\beta 1$ in the presence of osteoblasts decreases RANKL upregulation [66-68]. Two research teams recently demonstrated increased levels of TGF- $\beta 1$ after LLLT in the oral cavity $[69,70]$.

\section{LLLT and Cyclooxygenase 2 (Cox-2)}

Cyclo-oxygenase is the rate-limiting enzyme in the conversion of arachidonic acid to prostaglandins, which is an essential component in osteoclast regulation. Several authors have shown that both Cox-2 and PGE-2 upregulate RANKL and inhibit OPG levels [71-73]. Matsumoto and colleagues demonstrated increased expression of Cox-2 after LLLT during bone repair in rats [20].

\section{LLLT, fibronectin, PDL Collagen Remodeling}

During orthodontic tooth movement the cells and components of the periodontal membrane matrix surrounding teeth undergo remodeling as mechanical forces induce biochemical changes in the microenvironment [74]. Fibronectin and collagen type 1 are important components of PDL organization. Fibronectin is synthesized in osteoblasts and fibroblasts. Fibroblast plays an important role in adhesion, growth, cell movement and differentiation during PDL reorganization [75]. It is particularly important in wound healing. Collagen type 1 is the main component in the PDL and is present in the high concentration in all fibers responsible for maintaining tooth position [76].

Increased expression of Fibronectin and turnover of collagen type 1 in LLLT groups compared to controls from day one of the experiment was found by Kim and his team of researchers. This may be due to the fact that Fibronectin induce the upregulation of RANKL which leads to the differentiation of osteoclast [77-78]. Fibronectin could, therefore, serve multiple purposes in PDL and bone turnover by assisting in phagocytic cells migration as well as increasing the presence of osteoclast like cells. The increased rate of collagen type 1 degradation and reorganization may also assist in minor increases in orthodontic tooth movement.

\section{LLLT and Tissue Vascularity}

Vascularization plays a key role in orthodontic tooth movement. Regardless of the type of bone resorption, whether frontal or undermining resorption, key cellular constituents arrive to the sites of bone resorption and deposition through the blood vessels. Along with nascent osteoclast, other phagocytic cells make their way through vessels and assist in not only bone but also tissue remodeling. Histological sections have revealed accelerated deposition of bony matrix as well as nascent vascularization on the laser experimental sides after seven days of healing when compared to controls $[79,80]$. Other researchers have shown increased vascularity after laser therapy in non osseous organs [81-83] as well as an increase in molecular factors related to vascular proliferation $[84,85]$. Additionally, some investigators have also found an upregulation of eNOS gene expression via PI3K signal pathway allowing for increased angiogenesis, endothelial migration, and revascularization [86]. The complete biochemical pathways through which LLLT influences osteoclast activity are not fully understood. Yet these researchers provide potential mechanisms whereby LLLT can influence osteoclast regulation by effecting enzymatic levels of TGF- $\beta 1$, Cox- 2 , PGE- 2 , fibronectin, collagen turnover, and tissue vascularity preservation. These enzymes induce the expression or inhibition of members of the OPG/RANKL/RANK system and subsequently manipulate the differentiation, maturation, and maintenance of osteoclasts.

\section{Conclusion}

Orthodontic tooth movement is induced by mechanical stimuli and facilitated by the remodeling of the periodontal ligament and alveolar bone. The remodeling activities and the ultimately tooth displacement are the consequence of an inflammatory process. Vascular and cellular changes were the first events to be recognized. It is important for the clinicians to have knowledge of the effect of low level laser therapy on the cellular elements involved in orthodontic tooth movement. Orthodontically induced tooth movement associated with LLLT produced an increase in 


\section{Advances in Dentistry \& Oral Health}

the vascularization, controls mechanism of bone turnover by regulating the OPG/RANKL/RANK system. Low level laser also regulates Transforming Growth Factor Beta 1, Cyclooxygenase 2 (Cox-2), fibronectin, PDL Collagen Remodeling. Further research is required to develop more solid scientific bases for the clinical use of LLLT and to describe the mechanism action of low power lasers as there are only a few studies in this field and different methodologies have been employed.

\section{References}

1. Davidovitch Z, Nicolay OF, Ngan PW, Shanfeld JL (1988) Neurotransmitters, cytokines, and the control of alveolar bone remodeling in orthodontics. Dent Clin North Am 32(3): 411-435.

2. Krishnan V, Davidovitch Z (2006) Cellular, molecular, and tissue-level reactions to orthodontic force. Am J Orthod Dentofacial Orthop 129(4): 469 e $461-469$ e 432.

3. Davidovitch Z (1991) Tooth movement. Crit Rev Oral Biol Med 2(4): 411-450.

4. Mester E (1966) The use of the laser beam in therapy. Orv Hetil 107(22): 1012-1016.

5. Chen JW, Zhou YC (1989) Effect of low level carbondioxide laser radiation on biochemical metabolism of rabbit mandibular bone callus. Laser Therapy 1: 83-88.

6. Shimizu N, Yamaguchi M, Goseki T, Shibata Y, Takiguchi H, et al. (1995) Prospect of relieving pain due to tooth movement during orthodontic treatment utilizing a Ga-Al-As diode laser. Proc SPIE 1984: 275-280.

7. Zhang L, Xing D, Gao X, Wu S (2009) Low-power laser irradiation promotes cell proliferation by activating PI3K/Akt pathway. J Cell Physiol 219(3): 553-562.

8. Kawasaki K, Shimizu N (2000) Effects of low-energy laser irradiation on bone remodeling during experimental tooth movement in rats. Lasers Surg Med 26(3): 282-291.

9. Cruz DR, Kohara EK, Ribeiro MS, Wetter NU (2004) Effects of lowintensity laser therapy on the orthodontic movement velocity of human teeth: Lasers Surg Meda 35(2): 117-120.

10. Goulart CS, Nouer PRA, Mouramartins L, Garbin IU, de Fátima Zanirato Lizarelli R (2006) Photoradiation and orthodontic movement: experimental study with canines. Photomed Laser Surg 24(2): 192 196

11. Yamaguchi M, Fujita S, Yoshida T, Oikawa K, Utsunomiya T, et al. (2007) Low-energy laser irradiation stimulates the tooth movement velocity via expression of MCSF and c-fms. Ortho Waves 66(4): 139-148.

12. Youssef M, Ashkar S, Hamade E, Gutknecht N, Lampert F, et al. (2008) The effect of low-level laser therapy during orthodontic movement: a preliminary study. Lasers Med Sci 23(1): 27-33.

13. Fujita S, Yamaguchi M, Utsunomiya T, Yamamoto H, Kasai K (2008) Low-energy laser stimulates tooth movement velocity via expression of RANK and RANKL. Orthod Craniofac Res 11(3): 143-155.

14. Kim S, Moon S, Kang S, Park Y (2009) Effects of low-level laser therapy after Corticision on tooth movement and paradental remodeling. Lasers Surg Med 41(7): 524-533.

15. Yoshida T, Yamaguchi M, Utsunomiya T, Kato M, Arai Y, et al. (2009) Lowenergy laser irradiation accelerates the velocity of tooth movement via stimulation of the alveolar bone remodeling. Orthod Cranio fac Res 12(4): 289-298.

16. Limpanichkul W, Godfrey K, Srisuk N, Rattanayatikul C (2006) Effects of low-level laser therapy on the rate of orthodontic tooth movement. Orthod Craniofac Res 9(1): 38-43.
17. Gama SK, Habib FA, Monteiro JS, Paraguassu GM, Araujo TM, et al (2010) Tooth movement after infrared laser phototherapy: clinical study in rodents. Photomed Laser Surg 28: 79-83.

18. Marquezan M, Bolognese AM, Araujo MT (2010) Effects of two lowintensity laser therapy protocols on experimental tooth movement. Photomed Laser Surg 28(6): 757-762.

19. Seifi M, Shafeei HA, Daneshdoost S, Mir M (2007) Effects of two types of low-level laser wave lengths (850 and $630 \mathrm{~nm}$ ) on the orthodontic tooth movements in rabbits. Lasers Med Sci 22(4): 261-264.

20. Karu TI, Afanas'eva NI (1995) Cytochrome c oxidase as the primary photoacceptor upon laser exposure of cultured cells to visible and near IR-range light. Dokl Akad Nauk 342(5): 693-695.

21. W Yu, JO Naim, M McGowan, K Ippolito, R J (1997) Lanzafame, Photomodulation of oxidative metabolism and electron chain enzymes in rat liver mitochondria, Photochem Photobiol 66(6): 866-871.

22. Hamblin MR, Demidova TN (2006) Mechanisms of low level light therapy. In: Hamblin MR, et al. (Eds.), Mechanisms for low-light therapy. The International Society for Optical Engineering, San Jose, Calif. Proc. SPIE 6140. Bellingham, Wash. SPIE -614001-1 - 614001-12.

23. Karu T (2007) Ten lectures on basic science of laser phototherapy. Prima Books, Grängesberg, Sweden.

24. Ross G Ross A (2009) Photobiomodulation: An Invaluable Tool for All Dental Specialties. J Laser Dent 17(3): 117-124.

25. Kreisler M, Christofers AB, Willerstausen B, d'Hoedt B (2003) Effect of low-level GaAlAs laser irradiation on the proliferation rate of human periodontal ligament fibroblasts: An in vitro study. J Clin Periodontol 30(4): 353-358.

26. Qadri T, Miranda L, Tuner J, Gustafsson A (2005) The short-term effects of low-level lasers as adjunct therapy in the treatment of periodontal inflammation. J Clin Periodontol 32(7): 714-719

27. Khadra M (2005) The effect of low level laser irradiation on implanttissue interaction. In vivo and in vitro studies. Swed Dent J Suppl 172: $1-63$

28. Barushka O, Yaakobi T, Oron U (1995) Effect of low-energy laser (He--Ne) irradiation on the process of bone repair in the rat tibia. Bone 16(1): 47-55.

29. Nicola RA, Jorgetti V, Rigau J, Pacheco MTT, dos Reis LM, et al. (2003) Effect of low-power GaAlAs laser $(660 \mathrm{~nm})$ on bone structure and cell activity: an experimental animal study. Lasers Med sci 18(2): 89-94.

30. Dörtbudak O, Haas R, Mallath Pokorny G (2000) Biostimulation of bone marrow cells with a diode soft laser. Clin Oral Implants Res 11(6): 540545.

31. Shimizu N, Mayahara K, Kiyosaki T, Yamaguchi A, OzawaY, et al. (2007) Low-intensity laser irradiation stimulates bone nodule formation via insulin-like growth factor-I expression in rat calvarial cells. Lasers Surg Med 39(6): 551-559.

32. Fujihara NA, Hiraki KRN, Marques MM (2006) Irradiation at 780 $\mathrm{nm}$ increases proliferation rate of osteoblasts independently of dexamethasone presence. Lasers Surg Med 38(4): 332-336.

33. Hamajima S, Hiratsuka K, Kiyama Kishikawa M, Tagawa T, Kawahara M, et al. (2003) Effect of lowlevel laser irradiation on osteoglycin gene expression in osteoblasts. Lasers Med Sci 18(2): 78-82.

34. Ueda Y, Shimizu N (2003) Effects of pulse frequency of lowlevel laser therapy (LLLT) on bone nodule formation in rat calvarial cells. J Clin Laser Med Surg 21(5): 271-277.

35. Stein A, Benayahu D, Maltz L, Oron U (2005) Low-level laser irradiation promotes proliferation and differentiation of human osteoblasts in vitro. Photomed Laser Surg 23(2): 161-166 


\section{Advances in Dentistry \& Oral Health}

36. Renno ACM, McDonnell PA, Parizotto NA, Laakso E (2007) The effects of laser irradiation on osteoblast and osteosarcoma cell proliferation and differentiation in vitro. Photomed Laser Surg 25(4): 275-280.

37. Haxsen V, Schikora D, Sommer U, Remppis A, Greten J, et al. (2007) Relevance of laser irradiance threshold in the induction of alkaline phosphatase in human osteoblast cultures. Lasers Surg Med 23(4): 381-384.

38. Stein E, Koehn J, Sutter W, Wendtlandt G, Wanschitz F, et al. (2008) Initial effects of low-level laser therapy on growth and differentiation of human osteoblast-like cells. Wien Klin.Wochenschr 120(3-4): 112710

39. Roberts WE, Epker BN, Burr DB, Hartsfield J, Roberts JA (2006) Remodeling of mineralized tissues, Part II: Control and pathophysiology. Sem Orthod 12(4): 238-253.

40. Kim Y, Kim S, Hwang D, Kim S, Kwon Y, et al. (2007) Effect of lowlevel laser treatment after installation of dental titanium implantimmunohistochemical study of RANKL, RANK, OPG: an experimental study in rats. Lasers Surg Med 39(5): 441-450.

41. Barushka O, Yaakobi T, Oron U (1995) Effect of low-energylaser (He--Ne) irradiation on the process of bone repairin the rat tibia. Bone 16(1): 47-55.

42. Zhu X, Chen Y, Sun X (2002) A study on expression of basic fibroblast growth factors in periodontal tissue following orthodontic tooth movement associated with low power laser irradiation. WCJS 20(3) 166-168.

43. Garavello Freitas I, Baranauskas V, Joazeiro PP,Padovani CR, Dal Pai-Silva M, da et al. (2003) Low-power laser irradiation improves histomorphometrical parameters and bone matrix organization during tibia wound healing in rats. J Photochem Photobiol B Biol 70(2): 81-89.

44. Aihara N, Yamaguchi M, Kasai K (2006) Low-energy irradiation stimulates formation of osteoclast-like cells via RANK expression in vitro. Lasers Surg Med 21(1): 24-33.

45. Locklin RM, Khosla S, Turner RT, Riggs BL (2003) Mediators of the biphasic responses of bone to intermittent and continuously administered parathyroid hormone. J Cell Biochem 89(1): 180-90.

46. Kim Y, Kim S, Kim S, Kwon D, Jeon E, et al. (2008) Low-levellaser irradiation facilitates fibronectin and collagen type I turnover during tooth movement in rats. Lasers Med Sci25(1):25-31.

47. Aimbire F, Albertini R, Pacheco MTT, Castro-Faria-Neto HC, Leonardo PSLM, et al. (2006) Low-level laser therapy induces dose-dependent reduction of TNF alpha levels in acute inflammation. Photomed Laser Surg 24(1): 33-37.

48. Funk JO, Kruse A, Neustock P, Kirchner H (1993) Helium-neon laser irradiation induces effects on cytokine production at the protein and the mRNA level. Exp Dermatol 2(2):75-83

49. Yu HS, Chang KL, Yu CL, Chen JW, Chen GS (1996) Low-energy heliumneon laser irradiation stimulates interleukin-1 alpha and interleukin-8 release from cultured human keratinocytes. J Invest Dermatol 107(4) 593-596.

50. Albertini R, Aimbire FSC, Correa FI, Ribeiro W, Cogo JC, et al. (2004) Effects of different protocol doses of low power gallium-aluminumarsenate (Ga- Al-As) laser radiation $(650 \mathrm{~nm})$ on carrageenan induced rat paw oedema. J Photochem Photobiol B 174(2-30): 101-107.

51. Mizutani K, Musya Y, Wakae K, Kobayashi T, Tobe M,et al. (2004) A clinical study on serum prostaglandin E2 with low-level laser therapy. Photomed Laser Surg 22(6): 537-539.

52. Aimbire F, Albertine R, de Magalhães RG, Lopes-Martins RAB, CastroFaria-Neto HC, et al. (2005) Effect of LLLT Ga-Al-As (685 nm) on LPSinduced inflammation of the airway and lung in the rat. Lasers Med Sci 20(1): 11-20.
53. Rizzi CF, Mauriz JL, Freitas Corrêa DS, Moreira AJ, Zettler CG, et al. (2006) Effects of low-level laser therapy (LLLT) on the nuclear factor (NF)-kappaB signaling pathway in traumatized muscle. Lasers Surg Med 38(7): 704-713.

54. Aimbire F, Bjordal JM, Iversen VV, Albertini R, Frigo L, et al. (2006) Low level laser therapy partially restores trachea muscle relaxation response in rats with tumor necrosis factor alpha-mediated smooth airway muscle dysfunction. Lasers Surg Med 38(8): 773-778.

55. Gavish L, Perez L, Gertz SD (2006) Low-level laser irradiation modulates matrix metalloproteinase activity and gene expression in porcine aortic smooth muscle cells. Lasers Surg Med 38(8): 779-786.

56. Aimbire F, Lopes-Martins RAB, Castro-Faria-Neto HC, Albertini R, Chavantes MC, et al. (2006) Low-level laser therapy can reduce lipopolysaccharide-induced contractile force dysfunction and TNFalpha levels in rat diaphragm muscle. Lasers Med Sci 21(4): 238-244.

57. Lim W, Lee S, Kim I, Chung M, Kim M, et al. (2007) The anti-inflammatory mechanism of $635 \mathrm{~nm}$ light-emitting-diode irradiation compared with existing COX inhibitors. Lasers Surg Med 39(7): 614-21.

58. Albertini R, Villaverde AB, Aimbire F, Bjordal J, Brugnera A, et al. (2008) Cytokine mRNA expression is decreased in the subplantar muscle of rat paw subjected to carrageenan-induced inflammation after lowlevel laser therapy. Photomed Laser Surg 26(1): 19-24.

59. Aimbire F, Santos FV, Albertini R, Castro-Faria-Neto HC, Mittmann J, et al. (2008) Low-level laser therapy decreases levels of lung neutrophils anti-apoptotic factors by a NF-kappaB dependent mechanism. Int Immunopharmacol 8(4): 603-605.

60. Aimbire F, Ligeiro de Oliveira AP, Albertini R, Corrêa JC, Ladeira de Campos CB, et al. (2008) Low level laser therapy (LLLT) decreases pulmonary microvascular leakage, neutrophil influx and IL-1beta levels in airway and lung from rat subjected to LPS-induced inflammation. Inflammation 31(3): 189-197.

61. Gavish L, Perez LS, Reissman P, Gertz SD (2008) Irradiation with $780 \mathrm{~nm}$ diode laser attenuates inflammatory cytokines but upregulates nitric oxide in lipopolysaccharidestimulated macrophages: implications for the prevention of aneurysm progression. Lasers Surg Med 40(5): 371378.

62. Safavi SM, Kazemi B, Esmaeili M, Fallah A, Modarresi A, et al. (2008) Effects of low-level He-Ne laser irradiation on the gene expression of IL-1beta, TNF-alpha, IFN-gamma, TGFbeta, bFGF, and PDGF in rat's gingiva. Lasers Med Sci 23(3): 331-335.

63. Massey HM, Scopes J, Horton MA, Flanagan AM (2001) Transforming growth factor-beta1 (TGF-beta) stimulates the osteoclast-forming potential of peripheral blood hematopoietic precursors in a lymphocyte-rich microenvironment. Bon 28(6): 577-582.

64. Quinn JM, Itoh K, Udagawa N, Hausler K, Yasuda H, et al. (2001) Transforming growth factor beta affects osteoclast differentiation via direct and indirect actions. J Bone Miner Res 16(10): 1787-1794.

65. Itonaga I, Sabokbar A, Sun SG, Kudo O, Danks L, et al. (2004) Transforming growth factor-beta induces osteoclast formation in the absence of RANKL. Bone 34(1): 57-64.

66. Karst M, Gorny G, Galvin RJS, Oursler MJ (2004) Roles of stromal cell RANKL, OPG, and M-CSF expression in biphasic TGF-beta regulation of osteoclast differentiation. J Cell Physiol 200(1): 99-106.

67. Arany PR, Nayak RS, Hallikerimath S, Limaye AM, Kale AD, et al. (2007) Activation of latent TGF-beta1 by low-power laser in vitro correlates with increased TGF-beta1 levels in laser-enhanced oral wound healing. Wound Repair Regen 15(6): 866-874.

68. Sun X, Wang R, Zhang X (2006) Effects of He-Ne laser irradiation on the expression of transforming growth factor beta1 during experimental tooth movement in rabbits. Shanghai Kou Qiang Yi Xue 15(1): 52-7. 


\section{Advances in Dentistry \& Oral Health}

69. Liu X, Kirschenbaum A, Yao S, Levine AC (2006) Interactive effect of interleukin- 6 and prostaglandin E2 on osteoclastogenesis via the OPG/ RANKL/RANK system. Ann N Y Acad Sci 1068: 225-233.

70. Brechter AB, Lerner UH (2007) Bradykinin potentiates cytokineinduced prostaglandin biosynthesis in osteoblasts by enhanced expression of cyclooxygenase 2, resulting in increased RANKL expression. Arthritis Rheum 56(3): 910-923.

71. Coon D, Gulati A, Cowan C, He J (2007) The role of cyclooxygenase-2 (COX-2) in inflammatory bone resorption. J Endod 33(4): 432-436.

72. Matsumoto M, Ferino R, Monteleone G, Ribeiro D (2009) Lowlevel laser therapy modulates cyclo-oxygenase-2 expression during bone repair in rats. Lasers Med Sci 24(2): 195-201

73. Takahashi I, Onodera K, Nishimura M, Mitnai H, Sasano Y, et al. (2006) Expression of genes for gelatinases and tissue inhibitors of metalloproteinases in periodontal tissues during orthodontic tooth movement. J Mol Histol 37(8-9): 333-342.

74. Pankov R, Yamada KM (2002) Fibronectin at a glance. J Cell Sci 115: 3861-3.

75. Newman M, Takei H, Carranza F (2006) Carranza's Clinical Periodontology. 10th ed. Philidelphia: W.B. Saunders Co 2006:69.

76. Nakayamada S, Okada Y, Saito K, Tamura M, Tanaka Y (2003) Beta1 integrin/focal adhesion kinase-mediated signaling induces intercellular adhesion molecule 1 and receptor activator of nuclear factor kappaB ligand on osteoblasts and osteoclast maturation. J Biol Chem 278(46): 45368-74.

77. Nishiguchi M, Yuasa K, Saito K, Fukumoto E, Yamada A, et al. (2007) Amelogenin is a negative regulator of osteoclastogenesis via downregulation of RANKL, M-CSF and fibronectin expression in osteoblasts. Arch Oral Biol 52(3): 237-243
78. Garavello I, Baranauskas V, da Cruz-Höfling MA (2004) The effects of low laser irradiation on angiogenesis in injured rat tibiae. Histol Histopathol 19(1): 43-48.

79. Khadra M, Kasem N, Haanaes HR, Ellingsen JE, Lyngstadaas SP(2004) Enhancement of bone formation in rat calvarial bone defects using lowlevel laser therapy. Oral Surg Oral Med Oral Pathol Oral Radiol Endod 97(6): 693-700.

80. Schindl A, Schindl M, Schindl L, Jurecka W, Hönigsmann H, et al. (1999) Increased dermal angiogenesis after lowintensity laser therapy for a chronic radiation ulcer determined by a video measuring system. J Am Acad Dermatol 40(3): 481-484.

81. Mirsky N, Krispel Y, Shoshany Y, Maltz L, Oron U (2002) Promotion of angiogenesis by low energy laser irradiation. Antioxid Redox Signal 4(5): 785-790.

82. Corazza AV, Jorge J, Kurachi C, Bagnato VS (2007) Photobiomodulation on the angiogenesis of skin wounds in rats using different light sources. Photomed Laser Surg 25(2): 102-106.

83. Khanna A, Shankar LR, Keelan MH, Kornowski R, Leon M, et al. (1999) Augmentation of the expression of proangiogenic genes in cardiomyocytes with low dose laser irradiation in vitro. Cardiovasc Radiat Med 1(3): 265-269.

84. Hou J, Zhang H, Yuan X, Li J, Wei Y, (2008) In vitro effects of lowlevel laser irradiation for bone marrow mesenchymal stem cells: proliferation, growth factors secretion and myogenic differentiation. Lasers Surg Med 40(10): 726-733.

85. Chen C, Hung H, Hsu S (2008) Low-energy laser irradiation increases endothelial cell proliferation, migration, and eNOS gene expression possibly via PI3K signal pathway. Lasers Surg Med 40(1): 46-54. 